\title{
O papel da brincadeira de faz de conta no processo de humanização de crianças ribeirinhas da Amazônia
}

Sônia Regina dos Santos Teixeira*

\section{Resumo}

De acordo com a teoria histórico-cultural, o ser humano se humaniza reconstituindo em si e por si as características históricas da humanidade. Esse processo ocorre nas relaçôes sociais, via atividade humana mediada por instrumentos físicos e simbólicos. $\mathrm{Na}$ fase pré-escolar, a brincadeira de faz de conta é a atividade que guia esse processo. Ao brincar, a criança descobre e se apropria dos conteúdos de seu universo cultural, formando suas qualidades humanas. Nesse sentido, o objetivo do presente artigo é analisar e discutir o papel que a brincadeira de faz de conta desempenha no processo de humanização das crianças, a partir de uma pesquisa realizada com crianças de uma turma de educação infantil de uma escola ribeirinha da Amazônia. As brincadeiras foram transcritas, organizadas em episódios e analisadas de acordo com os princípios metodológicos da análise microgenética de matriz histórico-cultural. Os resultados demonstram que as crianças ribeirinhas da Ilha do Combu, por intermédio dos significados compartilhados com parceiros por ocasião das brincadeiras de faz de conta, internalizam suas relaçôes sociais, constituindo-se, por esta via, como ribeirinhos amazônidas.

Palavras-chave: Infância. Educação infantil. Amazônia.

* Doutora em Psicologia pela Universidade Federal do Pará (UFPA). Professora do Programa de Pós Graduaçãa em Educação do Instituto de Ciências da Educação da Universidade Federal do Pará (UFPA). 


\section{Introdução}

A Psicologia, da mesma forma que as demais ciências humanas construídas no bojo da modernidade, tendo o liberalismo como matriz de pensamento, produziu teorias que descrevem e explicam o psiquismo humano como uma construção individual, abstraindo as condiçóes concretas de vida sob as quais as pessoas se constituem como seres humanos. Em decorrência disso, o processo de desenvolvimento foi, geralmente, compreendido como algo universal, linear, homogêneo, fruto de uma acumulação gradual de mudanças isoladas, culminando com a fragmentação da criança em áreas ou aspectos do desenvolvimento e a ênfase dada a uma área específica por uma determinada teoria para explicar o processo como um todo.

A teoria histórico-cultural, desenvolvida pelo psicólogo russo Lev Vigotski e colaboradores, no início do século passado, representa uma ruptura a essa tradição. Tomando como fundamento teórico-metodológico o materialismo histórico e dialético de Marx e Engels, Vigotski empenhou-se em construir uma psicologia que superasse os limites das teorias clássicas da psicologia e explicasse a construção do psiquismo humano a partir de seus determinantes históricos e culturais.

Fundamentado na ideia de Marx de que o ser humano constitui-se nas relaçôes sociais, que são determinadas pelo modo de produção de uma sociedade em um dado momento histórico e concretizadas nas práticas sociais, Vigoski (2000a, 2000b) propôs uma equivalência entre as relaçôes sociais e as funçóes tipicamente humanas, por ele denominadas de funçóes psicológicas superiores. Para o autor, o que um novo indivíduo da espécie humana traz ao nascer é necessário, mas não suficiente para a sua vida em sociedade. Torna-se indispensável que ele construa as suas qualidades humanas, o que só é possível na interação com os outros e a cultura.

Nessa perspectiva, o desenvolvimento implica num processo de humanização ou de construção das funçôes psicológicas superiores, no qual cada criança participa na condiçấo de sujeito e o contexto histórico-cultural ${ }^{1}$ em que nasce, cresce e se desenvolve exerce um papel fundamental, atuando sobre ela para integrá-la à "complexa rede de relaçôes sociais e culturais que constituem uma formação social” (PINO, 1991, p. 34).

A opção de Vigotski pelo método dialético permitiu também a compreensão do desenvolvimento humano como um processo complexo caracterizado por saltos, crises e mudanças na relação entre as diversas funçóes psicológicas, provocando alteraçóes na qualidade da relação da criança com a sociedade da qual faz parte. Essas transformaçôes qualitativas, no entanto, não decorrem de um processo biológico, natural, mas da própria atividade da criança. Em cada período do desenvolvimento há uma atividade que guia esse processo gerando neoformaçóes. Na idade pré-escolar, compreendida 
entre três e seis anos de idade, a atividade que guia o processo de humanização do ser humano é a brincadeira de faz de conta. Ao brincar a criança internaliza a significação das relaçóes sociais em que está inserida na vida real, conferindo-lhes um sentido pessoal.

Face ao exposto, tendo como referência as teses fundamentais da teoria histórico-cultural, o objetivo deste artigo é analisar e discutir indícios do papel exercido pelas brincadeiras de faz de conta no processo de humanização de crianças que frequentam turmas de educação infantil, a partir de um estudo realizado com crianças de uma escola ribeirinha da Amazônia.

\section{O processo de humanização na perspectiva de Vigotski}

O mais básico consiste em que a pessoa não somente se desenvolve, mas também constrói a si. (VIGOTSKI, 2000a, p. 33).

Para Vigotski (2000a, 2000b), o processo de humanização ou de constituição cultural do homem é a história da transformação de um indivíduo da espécie homo sapiens em um representante do gênero humano. Trata-se do processo pelo qual cada criança se constituirá como sujeito, reconstituindo em si e por si, com os outros de seu grupo cultural, as características históricas da humanidade.

Conforme observou Pino (2005), o termo "humano" utilizado por Vigotski apresenta contornos bem diferentes das formas usuais que definem essa palavra. Fundamentado na tese do materialismo histórico e dialético de que a emergência da consciência na filogênese humana é um fenômeno historicamente situado, ligado à atividade produtora do homem, Vigotski utiliza esse termo para designar o ponto na relação homem natureza em que ocorre a emergência da consciência. Com isso, introduz no plano de desenvolvimento do indivíduo a problemática do desenvolvimento da espécie e a discussão sobre natureza e cultura.

De acordo com Pino (2005), Vigotski acreditava que a ontogênese náo implica numa repetiçáo da filogênese. No entanto, na medida em que o desenvolvimento da espécie homo sapiens (filogênese) é a história de sua humanização e a do desenvolvimento do indivíduo (ontogênese) é a história da humanização de cada membro da espécie, pode-se afirmar que a ontogênese é um caso particular da filogênese ou que a história pessoal de cada indivíduo da espécie homo é um caso particular da história geral da espécie. Precisar as semelhanças e diferenças entre essas duas histórias não é uma tarefa fácil, mas algo que pode mostrar a dimensão exata de escala entre as mesmas éque: 
[...] a humanização da espécie é uma 'tarefa coletiva' enquanto que a humanização de cada indivíduo é uma 'tarefa do coletivo', e, de outro lado, que a humanização da espécie confunde-se com o processo de produção da cultura, enquanto que a humanização de cada indivíduo confunde-se com o processo de apropriação dessa cultura. (PINO, 2005, p. 53).

Diante disso, podemos concluir, que apesar da diferença entre essas duas histórias, para Vigotski (2000a, 2000b), a história da humanização da espécie humana e a história de humanização de cada indivíduo da espécie constituem uma mesma e única história.

No entanto, assim como os detalhes sobre o processo de passagem do homem do estado da natureza para o estado da cultura ainda é algo bastante discutido entre os estudiosos, a questão acerca de como o indivíduo da espécie homo torna-se um representante do gênero humano também o é. Teóricos tradicionais da psicologia colocavam o eixo de suas análises na duplicidade de fatores, os fatores orgânicos ou biológicos de um lado e os fatores ambientais de outro, enfatizando ora uns, ora outros ou a interação entre ambos. Diferente desses autores, Vigotski (1994) explica essa questáo a partir da unidade dialética entre as linhas biológica e cultural, destacando o seu caráter cultural e sua origem social.

Diversos autores (GÓES, 1991; PINO, 1991, 2005; WERTSCH, TULVIST, 1992) têm mostrado que Vigotski valeu-se, principalmente, de duas grandes categorias teóricas para explicar como ocorre esse processo o conceito de funçóes psicológicas e o conceito de significação.

Para Vigotski (2000b, p. 150):

Podemos formular a lei genética geral do desenvolvimento cultural do seguinte modo: toda função no desenvolvimento da criança aparece em cena duas vezes, em dois planos; primeiro no plano social e depois no plano psicológico, a princípio entre as pessoas como categoria interpsíquica e logo no interior da criança como categoria intrapsíquica. $\mathrm{O}$ dito se refere por igual à atenção voluntária, à memória lógica, à formação de conceitos e ao desenvolvimento da vontade. Temos pleno direito de considerar a tese exposta como uma lei, mas a passagem, naturalmente do externo ao interno, modifica o próprio processo, transforma sua estrutura e funçóes. Por detrás de todas as funçóes superiores e suas relaçóes se encontram geneticamente relaçóes sociais, as autênticas relaçóes humanas. 
Observa-se na citação, a proposição de Vigotski (2000b) da relação fundante entre as funçôes psicológicas superiores, isto é, as tipicamente humanas e as relaçôes sociais. Entretanto, a transposição do plano interpsíquico para o intrapsíquico, ao contrário do que propóem algumas leituras da obra do autor, não é literal. As funçôes psicológicas superiores são frutos da reconstituição e não da reprodução, no plano pessoal, das experiências vividas coletivamente, o que só é possível devido à capacidade do ser humano criar e operar com signos. Foi o que demonstrou Vigotski (2000b), ao recorrer ao "ato de apontar", considerado por ele o protótipo do modo como ocorre o processo de internalização das funções psicológicas superiores. Um movimento natural da mão de uma criança em direção a um objeto - um ato em si, torna-se um ato significativo para o outro, ao ser interpretado por este como um "sinal" do que a criança quer e traduzido no atendimento da demanda da criança, dando-lhe o objeto desejado. Com isso, a criança descobre a significação do seu ato, em razão do qual este se torna para ela o signo - um ato para si, com o qual se comunicará, posteriormente, com outras pessoas, sempre que desejar o objeto.

Vemos no exemplo, que a função do ato mudou de um movimento, inicialmente, dirigido a um objeto para um movimento dirigido a outra pessoa e que isso só foi possível devido à significação atribuída pelo outro ao gesto de apontar da criança (fato natural), tornando-o um fato simbólico ou cultural. O movimento só se torna um ato para si, porque antes foi um ato para o outro. $\mathrm{O}$ que foi internalizado, portanto, não foi o gesto, mas o significado atribuído a ele pelo outro. Disso, conclui-se que significação é a via que permite a passagem do plano social para o plano pessoal. Esse processo é mediado pelos signos da cultura específica da qual uma criança faz parte que, gradativamente, são internalizados por ela num processo de apropriação ativa, possibilitando a transformação de suas funçóes elementares, reguladas por mecanismos biológicos em funçôes superiores, que são aprendidas e podem ser reguladas voluntariamente pela criança.

Nesse sentido, como ressalta Delari Júnior (2013), a teoria sobre o processo de humanização, proposta por Vigotski, é indissociável de uma proposição sobre significação, especialmente sobre o tema da linguagem, modo principal pelo qual os homens entram em relação.

O processo de tornar-se humano na história e como história náo é possível senáo na linguagem, não apenas porque é como linguagem que se dá a narração e memória histórica, mas também porque é na e pela linguagem que as próprias lutas humanas podem se desenvolver como tais. (DELARI JÚNIOR, 2013, p. 120-121). 
As formas de funcionamento psicológico culturalmente criadas, são constituídas e reconstituídas continuamente, via significação, nas relaçôes sociais concretas que os sujeitos participam. Isso aponta para a necessidade das investigaçóes inspiradas nessa abordagem teórica estudarem contextos sociais específicos e as interaçóes entre os sujeitos. Os contextos culturais são concretos ou objetivados nas produçôes culturais mediadoras das atividades humanas. Seus estudos podem indicar como os sujeitos concretos se humanizam em interação com seus contextos específicos de vida. As interaçôes são as formas pelos quais os sujeitos entram em relação. As análises de processos interativos fornecem algumas evidências empíricas sobre várias questóes teóricas formuladas por Vigotski acerca do processo de humanização.

\section{Brincadeira de faz de conta e humanização}

A brincadeira de faz de conta foi concebida, tradicionalmente, pelas teorias clássicas da psicologia como uma manifestação natural da criança, que deve ser valorizada pelo seu caráter lúdico ou de recreação e entretenimento, culminando com a cristalização da ideia de que brincar é algo "naturalmente infantil", fruto de uma mente imaginativa e ociosa. Vigotski $(2003,2008)$ rompeu com essa ideia e sinalizou que na infância não há nada mais sério e complexo do que brincar de faz de conta. Ele foi um dos primeiros estudiosos a mostrar o vínculo existente entre a brincadeira de faz de conta e o contexto concreto de vida das crianças e a demonstrar como ocorre o processo de internalização das relaçóes sociais nessa atividade.

No texto "A brincadeira e o seu papel no desenvolvimento psíquico da criança", Vigotski (2008) examinou as concepçôes sobre brincadeira presentes em seu tempo e considerou que as características que elas propunham como definidoras dessa atividade não davam conta dessa questão.

$\mathrm{Na}$ sua perspectiva, a brincadeira de faz de conta emerge como resultado de uma contradição que se apresenta à criança no início da idade pré-escolar, devido ao fato dela experimentar necessidades e desejos sociais específicos dessa fase, que não podem ser imediatamente satisfeitos, e às transformaçôes ocorridas em sua memória, que não mais a permitem esquecer tais necessidades e desejos. Para resolver esse conflito, a criança envolve-se em uma situação imaginária: "Parece-me que é esse o critério que deve ser adotado para distinguir a atividade de brincar dentro do grupo geral de outras atividades da criança” (VIGOTSKI, 2008, p. 26). Porém, ao brincar de faz de conta, uma criança não pode criar quaisquer situaçôes imaginárias. Suas criaçôes estão sempre vinculadas às regras do seu mundo real, aos conteúdos culturais de seu grupo social. 
A possibilidade de a criança atuar num mundo imaginário e de lidar com os significados social e historicamente produzidos e de criar novos significados, permitiram a Vigotski (2008, p. 24) afirmar que a brincadeira é "a linha principal do desenvolvimento na idade pré-escolar”, a atividade que guia o processo de humanização nessa fase, contribuindo para a formação das funçôes psicológicas superiores na criança.

Elkonin (1998), Leontiev (1988) e Mukhina (1995) ampliaram as ideias de Vigotski acerca do papel da brincadeira de faz de conta no processo de humanização da criança.

Elkonin (1998), coerente com a orientaçáo marxista de que os fenômenos devem ser estudados como um todo e não em suas partes constituintes, preocupou-se em encontrar a unidade de análise da brincadeira de faz de conta e concluiu que essa unidade são os conteúdos da realidade concreta de vida das crianças, que são reconstituídos nas açóes durante as brincadeiras.

O conteúdo do jogo é o aspecto característico central, reconstituído pela criança a partir da atividade dos adultos e das relaçóes que estabelecem em sua vida social e de trabalho. $\mathrm{O}$ conteúdo do jogo revela a penetração mais ou menos profunda da criança na atividade dos adultos; pode revelar somente o aspecto externo da atividade humana, ou o objeto com o qual o homem opera ou a atitude que adota diante de sua atividade e a das outras pessoas ou, por último, o sentido social do trabalho humano. (ELKONIN, 1998, p. 35).

Para demonstrar melhor a vinculação da brincadeira aos contextos concretos de vida das crianças, Elkonin (1998) dividiu os conteúdos dessa atividade em duas esferas distintas e interdependentes: a esfera dos objetos e a esfera das atividades e relaçôes das pessoas e concluiu que esta última exerce um papel preponderante. Assim, a base da brincadeira de faz de conta, em sua forma evoluída "Não é a relação homem-objeto, mas a relação homem-homem" (ELKONIN, 1998, p. 34).

Elkonin (1998) considera que a brincadeira por si só é importante para o desenvolvimento cultural da criança. No entanto, a brincadeira individual mostra-se limitada se comparada à brincadeira coletiva, pela possibilidade das crianças, em grupo, interagirem verbalmente, principalmente representando papéis nos quais podem reconstituir aspectos importantes de suas vivências concretas. Ela representa uma possibilidade real das crianças cooperarem entre si e, ao fazê-lo, necessitarem continuamente mudar de posição e coordenar o próprio ponto de vista com os dos demais participantes sobre os significados atribuídos a objetos, papéis e relaçôes sociais. Além disso, cada criança que brinca trata seu parceiro de brincadeira a partir de sua nova 
postura, determinada pelo papel que assumiu e não mais da forma como o trata na vida real, ajustando as suas açóes individuais com o papel de companheiro de determinada brincadeira.

Leontiev (1988) também apresenta elementos teóricos importantes que nos permitem compreender o papel da brincadeira de faz de conta no processo de humanização. Para o autor, apesar de encontrarmos a atividade lúdica em certos animais superiores, a diferença entre a brincadeira dos animais e a humana é que esta náo é instintiva, mas objetiva. Seus conteúdos são baseados na percepçáo que a criança tem do mundo real em que vive, dos objetos e das atividades humanas. A brincadeira surge exatamente da tentativa da criança de apropriar-se do mundo humano, da sua necessidade de agir sobre ele. É a discrepância entre essa necessidade e as condiçóes reais de executar as operaçóes exigidas pelas açóes que leva uma criança a brincar. Por isso, o que caracteriza essa atividade é o fato de seu objetivo não estar no resultado, mas no processo, na ação em si mesma, no conteúdo da própria ação.

Mukhina (1995) concorda com Vigotski, Elkonin e Leontiev que a criança brinca de faz de conta para satisfazer seus desejos de conviver com os adultos, reproduzindo e ressignificando de forma lúdica as relaçôes e atividades dos mesmos e amplia essa ideia, mostrando em seus estudos que a forma da criança pré-escolar reproduzir e ressignificar a realidade não é a mesma. Conforme avança na idade, a criança compreende cada vez melhor o mundo dos adultos e a representa de um modo mais complexo. A autora identifica três períodos distintos na fase pré-escolar, caracterizados pelas experiências vivenciadas pelas crianças: pré-escolar ${ }^{2}$ mais novo (3 a 4 anos), pré-escolar mediano ( 4 a 5 anos) e pré-escolar mais velho (6 a 7 anos). Em cada um deles, a criança representa a realidade tal como a concebe. Isso pode ser verificado no que Mukhina (1995) denominou de argumento e conteúdo das brincadeiras e nas relaçôes estabelecidas durante as mesmas.

$\mathrm{O}$ argumento representa o eixo central da brincadeira. Diz respeito aos aspectos da realidade, notadamente, as atividades dos adultos, representados pelas crianças nas brincadeiras. São exemplos de argumentos as brincadeiras de mamãe-filhinha, de escola, polícia e ladrão, comidinha, entre outros.

Segundo Mukhina (1995), quanto mais ampla e diversa for a realidade da criança, mais variados e amplos serão seus argumentos de faz de conta. Além disso, eles se tornam mais complexos e variados conforme ela avança na idade pré-escolar, e que aumenta também a duração do faz de conta. Assim, uma criança na fase pré-escolar menor (3 a 4 anos), geralmente, tem um número mais limitado de argumentos e as brincadeiras, consequentemente, tem uma menor duração, se comparado com uma criança pré-escolar maior (6 a 7 anos). 
O conteúdo da brincadeira é aquilo que a criança destaca como aspecto principal na realidade representada. As crianças em idades diferentes introduzem conteúdos distintos nos mesmos argumentos.

O conteúdo principal das brincadeiras do pré-escolar mais novo ( 3 a 4 anos) é a reconstituição das açôes reais dos adultos com objetos. Nesse período, a criança repete várias vezes a mesma ação com os mesmos objetos e não costuma planejar, a priori, as brincadeiras. Elas surgem de acordo com o objeto que a criança tem na mão.

O conteúdo principal das brincadeiras do pré-escolar mediano são as relaçóes entre as pessoas. A criança não mais repete muitas vezes a mesma ação, mas a cada ação se segue outra. Tal ação não tem um fim em si. Serve para a criança expressar uma atitude em relação à outra pessoa, de acordo com o papel desempenhado. Ela buscará um parceiro para brincar, mas em caso da inexistência do mesmo, poderá realizar tal ação, por exemplo, com uma boneca, a qual conferirá determinado papel.

Mukhina (1995) destaca que os conteúdos vividos nesse período são fundamentais para o processo de humanização da criança. A interpretação detalhada das relaçôes entre os homens a ensina a observar as regras do seu grupo social. Além disso, permite que ela conheça a vida social dos adultos e compreenda melhor as funçóes sociais e as regras pelas quais os adultos regem suas relaçóes.

As brincadeiras do pré-escolar mais velho têm como conteúdo principal o respeito às regras do papel que eles assumem ao brincar. A criança desse período cumpre rigorosamente as regras e insiste com os parceiros para que façam as coisas tal como são feitas na realidade, o que, geralmente, torna-se motivo de discussôes frequentes entre eles.

Considero que é essa a grande contribuição de Vigotski e demais autores da teoria histórico-cultural para o estudo da brincadeira de faz conta. Seus méritos estáo em mostrar o vínculo existente entre brincadeira de faz de conta e o processo de humanização da criança, ampliando e qualificando a discussáo sobre o papel dessa atividade infantil.

De acordo com essa perspectiva teórica, a brincadeira de faz de conta é uma atividade social, histórica e culturalmente situada, mediada socialmente e produtora de significados, processando-se no campo das relaçôes intersubjetivas ou dialógicas. Constitui a atividade principal da criança pré-escolar não por ser a mais frequente, mas por atuar como um catalisador em torno do qual se desenvolvem importantes funçôes psicológicas, como a memória, a ação voluntária, o pensamento abstrato, a afetividade e a imaginação (inédita neoformação na criança que surge na fase pré-escolar decorrente da brincadeira de faz de conta). 
Desse modo, certa de que a brincadeira de faz de conta, especialmente, as interaçôes que ocorrem durante essa atividade, fornecem algumas evidências empíricas sobre várias questóes teóricas formuladas por Vigotski e demais autores da teoria histórico-cultural, acerca do processo de humanização da criança, analiso e discuto, neste estudo, indícios acerca do papel que essa atividade desempenha no processo de humanização de crianças em idade pré-escolar de uma turma de educação infantil de uma escola ribeirinha da Amazônia.

\section{Método}

\section{Participantes}

Participaram do estudo dezesseis crianças com idade entre três e cinco anos, sendo dez meninos e seis meninas, que frequentavam, no ano de 2005, a turma de Educação Infantil da Unidade Pedagógica da Ilha do Combu, localizada na comunidade ribeirinha de mesmo nome, pertencente ao município de Belém-Pará.

\section{Procedimentos da coleta de informaçôes}

A coleta de informaçóes foi realizada em duas etapas distintas. Primeiramente, visando efetuar a caracterização do contexto histórico-cultural de vida das crianças da turma de educação infantil, visitei cada criança em sua residência. Além disso, realizei entrevistas com a professora da turma, com as próprias crianças e com os responsáveis por elas. Concluí essa fase da pesquisa com a observação das crianças no ambiente doméstico e na comunidade de um modo geral.

A segunda etapa consistiu no registro em vídeo das brincadeiras que ocorriam no contexto da turma de Educação Infantil. Para garantir o registro completo das falas, realizei também a gravação do áudio em um gravador digital de voz e escrevi em um diário de campo as atividades e eventos mais significativos observados a cada dia.

A coleta, nessa segunda etapa, foi realizada quinzenalmente, ao longo do ano letivo de 2005, em dois períodos distintos: março a junho e agosto a dezembro, perfazendo um total de 16 registros, com duração média de 2 horas cada.

\section{Procedimentos de análise}

As brincadeiras foram analisadas de acordo com os princípios do método genético ou abordagem microgenética de matriz histórico-cultural (GÓES, 2000). Essa opção metodológica se mostra coerente com as ideias de Vigotski e demais autores da teoria histórico-cultural, pois permite ao pesquisador reconstruir o percurso do ser humano no seu processo de humanização. 
Em razão do objetivo do estudo, construí o processo de análise da seguinte maneira: assisti aos vídeos com as sessóes gravadas, transcrevi as falas das crianças por ocasião das brincadeiras, organizei as falas em turnos e, finalmente, recortei e selecionei os episódios que considero profícuos para analisar e discutir o papel da brincadeira de faz de conta no processo de humanização das crianças da turma de educação infantil.

Episódio e turno são aqui definidos de acordo com a proposição de Amaral e Mortimer (2006, p. 263): o primeiro refere-se a "um conjunto de enunciados que cria o contexto para a emergência de um determinado significado ou de alguns significados relacionados" e o segundo é compreendido como cada segmento do episódio, constituindo uma unidade de análise a partir do qual é possível reconstituir toda a sequência interativa, num movimento de síntese. Para dar conta das peculiaridades típicas das brincadeiras de faz de conta, ampliei o conceito de episódio, definindo-o como um conjunto de enunciados que versa sobre um mesmo tema, independente da mudança dos participantes.

\section{Resultados e discussão}

\section{A comunidade ribeirinha da Ilha do Combu}

A comunidade da Ilha do Combu habita a ilha de mesmo nome, que fica localizada ao sul do município de Belém, no Estado do Pará, à margem esquerda do rio Guamá, abrangendo uma área total de aproximadamente 15 quilômetros quadrados, a uma distância de $1,5 \mathrm{Km}$ da cidade de Belém, percurso cumprido, geralmente, em torno de quinze minutos em uma embarcação motorizada.

A Ilha do Combu é uma área de floresta natural, composta por árvores e arbustos, sendo a Euterpe oleracea martius, pertencente à família das palmáceas, conhecido popularmente por açaizeiro, a sua planta mais característica. Trata-se de uma palmeira ornamental, levemente curva e caule liso, com múltiplos troncos de até $25 \mathrm{~cm}$ de altura, que produz o açaí, nome de origem indígena "içá-çai", que significa a fruta que chora, fruto pequeno e arredondado, da cor roxa, que nasce em cachos, de onde se extrai o açaí propriamente dito, espécie de suco bastante denso, preparado a partir do amolecimento do fruto, despolpamento e adição de água. Embora, na Ilha, não existam mais açaizeiros em abundância, como tempos atrás, eles ainda podem ser encontrados em grande número nas margens dos rios e igarapés da Ilha, sendo o extrativismo do açaí a atividade econômica predominante na comunidade.

A hidrografia da Ilha do Combu é formada pelo rio Guamá, por furos e igarapés. O rio Guamá apresenta um movimento diário de marés, que alterna entre períodos de enchentes e vazantes, funcionando como um importante dinamizador das atividades 
dos moradores da Ilha. As águas constituem-se os espaços da pesca, especialmente do camarão e de outras atividades geradoras de renda, como a realização de travessias, transporte de produtos para Belém e vice-versa, ou ainda, pequenas vendas desenvolvidas em Belém e na própria ilha.

$\mathrm{Na}$ época da pesquisa, a população da Ilha era formada por cerca de 375 famílias ou aproximadamente 1700 moradores (BELÉM, 2001), que se concentravam em quatro pequenas comunidades: Igarapé do Combu, Igarapé do Piriquitaquara, Furo da Paciência e Beira do Rio Guamá. A grande extensão territorial da Ilha dificulta a relação de vizinhança entre as pessoas da comunidade, muitas vezes, isolando-as em suas residências.

O fato de essa comunidade organizar seu modo de vida integrado à pesca e ao extrativismo vegetal, vivendo em função do rio e da floresta, permite incluir essa população na categoria "ribeirinhos da Amazônia" (LOUREIRO, 2000; HARRIS, 2000). Loureiro (2000) afirma que a cultura produzida pelos ribeirinhos da Amazônia constitui-se na mais alta expressão da cultura amazônica por resguardar traços originais da experiência social acumulada e da criatividade dos povos indígenas, maiores responsáveis pela formação econômica e social da região.

Não se tem um registro exato sobre o início da ocupação da Ilha, mas autores como Dergan (2006) e Freire (2002) inferem, a partir de estudos da historiografia regional e de relatos orais de antigos moradores da ilha, que é possível que o processo de ocupação tenha iniciado ainda na segunda metade do século XIX.

A localização próxima à cidade de Belém, capital do estado do Pará, possibilita que o modo de vida nessa comunidade apresente contornos bem peculiares, diferente da maioria das comunidades ribeirinhas da Amazônia. Para uma parte da populaçáo da ilha, o trânsito nessa dupla realidade constitui uma rotina diária. A travessia é necessária para vender a produção dos moradores, efetuar compras, frequentar aulas ou realizar pequenos serviços.

A Ilha conta com uma única escola, ligada à rede pública do município de Belém. Na época da pesquisa funcionava nos turnos da manhã e tarde, com uma turma de educação infantil e três turmas do Ensino Fundamental - $1^{\circ}$ ao $5^{\circ}$ Ano. Dada a pouca infraestrutura existente na Ilha, a escola assume uma importância capital. Para as crianças é o lócus do saber, do lazer e da interação com seus pares. Para os adultos é o local das reuniôes, discussões e tomadas de decisôes da comunidade.

\section{Atividades econômicas dos adultos}

As atividades econômicas dos ribeirinhos da Ilha do Combu estáo relacionadas diretamente com a natureza, especialmente, com o rio Guamá e a floresta. 
O rio Guamá, os furos e igarapés são os locais da pesca de peixes regionais e do camarão, que é capturado com o auxílio do matapi, artefato de forma cilíndrica, confeccionado com talas de jupati, nome popular da Rhaphia taedigera, planta da família das palmáceas. Além disso, o rio possibilita a realização de transporte de pessoas e produtos da Ilha para Belém e vice-versa.

A floresta é o local de extração do açaí, principal atividade econômica dos adultos da Ilha. Os frutos coletados pelas famílias são transportados para Belém e comercializados nos portos da cidade, principalmente no Porto da Palha, principal entreposto comercial das ilhas da orla sul do município de Belém, localizado no bairro da Condor, às margens do rio Guamá. No período de safra, compreendido entre os meses de junho e novembro, época com menor intensidade de chuvas na regiáo, uma rasa, espécie de paneiro, usado no acondicionamento dos frutos do açaí, contendo o equivalente a 40 litros do fruto, chega a ser comercializada ao preço de $\mathrm{R} \$ 12,00$ a $\mathrm{R} \$ 30,00$. No período de entressafra, que ocorre nos meses mais chuvosos, entre dezembro e maio, o açaí colhido é utilizado basicamente para o consumo das famílias, que aproveitam esse período para desbastar as touças e remover as árvores velhas. Além do açaí, os ilhéus extraem outros frutos da floresta, tais como cacau, cupuaçu, ingá, taperebá e buruti ou miriti, porém, em menor quantidade.

Em todas as famílias das crianças da turma de educação infantil, o homem era o principal provedor dos recursos materiais para o sustento do lar. As mulheres ocupavam-se, principalmente, com os trabalhos domésticos e os cuidados com as crianças, embora também colaborassem tanto na pesca quanto no extrativismo do açaí.

\section{As atividades das crianças ribeirinhas da Ilha do Combu}

As atividades das crianças ribeirinhas da Ilha do Combu estão profundamente relacionadas às atividades desenvolvidas pelos adultos, especialmente, por seus pais. Elas participam ativamente de todos os momentos da vida em comunidade, no trabalho, em casa, no lazer e na religião.

Ainda muito pequenas, as crianças veem seus pais acordarem cedo e adentrarem nas matas de seus terrenos em busca dos cachos de açaí, mas raramente os acompanham, pois este é considerado pelos adultos como um trabalho árduo e perigoso. Eles temem pela presença de animais da floresta, principalmente, insetos, pela exposição ao sol e à chuva e pela viagem de ida e vinda. A participação das crianças nessa atividade ocorre, geralmente, na etapa seguinte, que é a fase de seleção dos frutos, ocasião em que ajudam os adultos a escolherem os frutos bons e eliminarem os ruins.

A pesca também é muito importante na configuração das atividades infantis.

Apesar de não acompanharem diretamente seus pais nessa atividade, as crianças 
demonstram grande interesse pelos resultados das pescarias, pelo processo de confecção e manutenção dos instrumentos de pesca e pelos desdobramentos das técnicas de pescaria utilizadas pelos adultos da comunidade. Elas também se interessam pelas embarcaçôes de suas famílias, uma vez que toda família da Ilha tem pelo menos um casco, embarcação típica das comunidades ribeirinhas, espécie de canoa sem banco, feita de uma só peça de madeira e conduzida a remos. As crianças maiores, algumas vezes, brincam de pilotar os cascos em frente às suas casas. Além disso, interessam-se pela manutenção e construção das embarcações.

Todas as residências das crianças da turma de educação infantil apresentavam um mesmo padrão, consoante com o tipo de habitaçáo característico das comunidades ribeirinhas da Amazônia. Eram casas de madeira, cobertas de telha de barro ou amianto e com pisos de assoalho, localizadas às margens do rio Guamá ou do igarapé do Combu e afastadas umas das outras, o que desfavorece a interação entre as crianças. Com exceção da escola, esse era praticamente o único espaço de convivência, muitas vezes, restringindo-se à convivência entre irmãos que habitavam uma mesma casa. Nesses locais, as crianças costumavam organizar suas brincadeiras nos terreiros, nas pontes ou na margem do rio ou do igarapé.

\section{As brincadeiras das crianças na turma de Educação Infantil}

A "Unidade Pedagógica da Ilha do Combu" localiza-se às margens do igarapé do Combu e foi construída pela Prefeitura Municipal de Belém no ano de 1999. Na época da pesquisa, a escola possuía duas salas de aula em forma de maloca, onde funcionavam, pela manhá, uma turma de Educação Infantil e uma dos primeiros anos do ensino fundamental e, no período da tarde, duas turmas dos primeiros anos do ensino fundamental.

A turma de educação infantil era formada por dezesseis crianças em idade préescolar. A professora da turma de educação infantil tinha formação superior em Pedagogia e havia frequentado cursos de formação continuada na área de educação infantil. Morava na cidade de Belém e trabalhava na Unidade Pedagógica da Ilha há cinco anos, desempenhando as funçôes de professora, coordenadora da Unidade e interlocutora da comunidade junto aos órgãos que tinham algum tipo de projeto social na Ilha. Além de ministrar aulas na classe de educação infantil, a professora também era responsável por uma turma do ensino fundamental, no turno vespertino, o que a compelia a permanecer nos dois turnos na escola, aproveitando o intervalo entre eles para visitar as residências das crianças, principalmente, daquelas que apresentavam baixa frequência ou algum tipo de problema na escola. Apesar de não ser nativa, demonstrava conhecimento e familiaridade com a cultura local, além de afeto e interesse pelas crianças. 
A sala de referência da educação infantil possuía um quadro de giz, um mural, uma mesa com cadeira para a professora, seis mesas com quatro cadeiras pequenas em cada uma, uma estante e três armários onde eram guardados materiais didáticos, jogos de construção e encaixe e alguns brinquedos industrializados. A professora destinava tempo em seu planejamento pedagógico para as brincadeiras de faz de conta e, geralmente, solicitava que as crianças recolhessem materiais provenientes da natureza nos terreiros de suas casas, na beira do rio ou igarapé e trouxessem para brincar na escola.

Para analisar e discutir o papel das brincadeiras de faz de conta no processo de humanização das crianças da turma de educação infantil, apresento, a seguir, a transcrição na íntegra dos diálogos de dois episódios que se processaram no contexto da turma de educação infantil e suas respectivas análises microgenéticas.

\section{Episódio 1: Tomando banho na maré}

Os participantes deste episódio foram Clara ( 5 anos), Lucas (5 anos e dois meses), Marcos ( 4 anos e um mês) e Paulo (5 anos).

Lucas, Clara e Marcos brincam em um canto da sala. Clara está com uma boneca na mão e os três meninos com alguns brinquedos, como barcos e peças de um jogo de montar. Clara inicia um diálogo com os meninos:

Turno 1 - Clara: Meu filho já sabe subir na árvore. Ele sobe e não cai.

Turno 2 - Lucas: Não cai? Então ele já sabe. Mas ele ainda não sabe tomar banho na maré.

Turno 3 - Clara: Sabe.

Turno 4 - Lucas: Então, vamos lá no igarapé ver se ele sabe.

Turno 5 - Clara: Vamos. (Clara se levanta com a boneca na máo e acompanha Lucas, que se dirige a um outro canto da sala. Marcos e Paulo também o acompanham).

Turno 6-Marcos: Ele vai é morrer afogado.

Turno 7 - Clara: Não vai não. Ele já sabe nadar.

Turno 8 - Marcos: Ela diz que o filho dela sabe tudo. (As crianças chegam ao local proposto por Lucas e ele fala).

Turno 9 - Lucas: Isso que eu quero ver. Pronto, põe ele na água. Vamos ver se ele sabe tomar banho na maré. (Clara pega a boneca e vai colocando bem devagar no chão, como se a estivesse colocando na água). Agora vem a água da maré. Olha a água chegando. Está ficando forte, forte. (Todos olham para a boneca imóvel no chão). É, o filho dela parece que não tem medo. Acho que ele já sabe tomar banho na maré.

As crianças participantes do episódio descrito tinham idade variando entre 4 a 5 anos, período denominado por Mukhina (1995) de pré-escolar mediano. Elas não 
chegaram a combinar a priori sobre o que iam brincar. Os acordos foram tácitos. Não conversaram sobre os significados atribuídos aos objetos e açóes e nem mesmo sobre os papéis a serem desempenhados. Cada criança pegou um objeto e atribuiu-lhe um significado particular, porém, todos tacitamente aceitaram que a boneca era a "filha" de Clara. Não questionaram, sequer, o fato da menina denominar a boneca de filho e não de filha, como é comum entre as crianças. A brincadeira surgiu do desafio dos meninos acerca dos "saberes" do filho de Clara, que se sentiu compelida durante todo o episódio a provar aos parceiros que o filho dela sabia realizar coisas que eles consideravam importantes para uma criança.

Lucas, Marcos e Clara mantiveram relaçôes lúdicas durante toda a brincadeira, mas apenas a menina desempenhou um papel propriamente dito, o de uma mãe de uma criança ribeirinha que sabe fazer as coisas que as crianças desse lugar deveriam saber fazer. Apesar disso, a brincadeira só ocorreu pela insistência dos parceiros, que duvidaram das habilidades do filho dela e, praticamente, a impeliram a desempenhar tal papel. Embora eles não tenham desempenhado um papel específico, ao interagirem com Clara ampliaram a compreensão que ela tinha acerca dos fazeres de uma criança ribeirinha. Tanto Lucas, que propôs que o canto da sala fosse o igarapé, quanto Marcos, que sugeriu que o filho de Clara podia morrer afogado, mostraram ter conhecimento sobre essa prática cultural e complementaram o conteúdo do argumento da brincadeira, além de terem motivado a menina a brincar.

Neste episódio, o argumento dos participantes era o banho na maré, uma prática cultural da Ilha do Combu. O conteúdo principal da brincadeira era a relação entre os adultos e as crianças da Ilha. Vemos Clara desempenhando o papel de uma mãe ribeirinha que se orgulha dos conhecimentos do filho, representado por uma boneca (Turno 1 - Meu filho já sabe subir na árvore. Ele sobe não cai). Isso demonstra que subir em árvore é um saber valorizado nesse contexto histórico-cultural e que as mães têm expectativas que seus filhos desenvolvam esse saber. As crianças que interagiram com Clara compreenderam que subir em árvore é um saber importante, mas que no contexto em que vivem, além desse saber, existem outros não menos importantes, como, por exemplo, saber nadar e tomar banho na maré. Além disso, as crianças conheciam os conteúdos da prática cultural representada na brincadeira. Sabiam por exemplo, que para tomar banho na maré, a pessoa precisa saber nadar e náo ter medo da água profunda nem de correntezas. Sabiam também que é preciso saber subir em árvore para não cair. Que se aprende primeiro subir em árvore e depois a tomar banho na maré. Compreendiam que é preciso saber nadar para não morrer afogado e que quem sabe nadar não tem medo da maré.

$\mathrm{O}$ estudo do contexto concreto de vida das crianças permite inferir que estes significados se originam das experiências cotidianas das crianças ribeirinhas com 
árvores e com a maré e das interaçôes com membros mais experientes da cultura, que cuidam das crianças.

É possível também perceber que os significados não foram produzidos por um único sujeito, mas são resultados das interaçôes, que incluem sujeitos em papéis complementares: a mãe que diz o que o filho sabe fazer e os outros que duvidam e pedem que ela demonstre.

O faz de conta favorece a simbolizaçáo e, consequentemente, o distanciamento das situaçóes concretas imediatas. Nesse sentido, as crianças, ao agirem e se posicionarem na representação de papéis complementares - uma mãe que defendia seu filho e parceiros que duvidavam dela -, demonstraram como estáo experimentando subjetivamente suas relaçôes sociais e atribuindo-lhes significados que foram ou estão sendo internalizados, contribuindo para o processo de humanizaçáo das crianças.

\section{Episódio 2: brincando de assarpeixe}

Os integrantes deste episódio foram Alice ( 5 anos e sete meses), Carol ( 5 anos e dois meses), Clara (5 anos), Mariana (3 anos e 11 meses), Paulo (5 anos) e Júlio (3 anos e 11 meses).

Carol prepara um "fogo" com pedras, pedaços de telha e folhas em cima de uma cadeira. Coloca um encosto de uma carteira que ela recolheu no terreiro para representar a grelha e começa a "assar" raízes, fazendo de conta que são peixes. Clara se aproxima de Carol:

Turno 1 - Carol: Clara, vamos assar os peixes? (Carol e Clara começam a fazer de conta que estão assando peixes. Mariana, que brincava de irmã com Alice também se aproxima e pede um peixe de Carol).

Turno 2-Mariana: Me dá um peixe? (Carol dá uma raiz à Mariana).

Turno 3 - Carol: Tem que escamar. (Mariana faz de conta que está escamando o peixe. Alice se aproxima e fica olhando as outras crianças prepararem o peixe).

Turno 4 - Alice: Já está pronta a boia?

Turno 5 - Mariana: Não. Tem que escamar.

Turno 6 - Alice: Que peixe é esse?

Turno 7 - Mariana: É mapará.

Turno 8 - Carol: (Coloca as raízes em cima do "fogo". Dá um tempo e fala) Pronto. Já está assado. (Em seguida, oferece um pouco de peixe assado à Alice que faz de conta que come e, na sequência, dá um pouco à Clara).

Turno 9 - Clara: Vizinha, essa comida estava tão gostosa, depois eu volto pra comer a sobremesa. (Clara se distancia do grupo. Carol e Alice começam a distribuir "peixe 
assado" para as demais crianças. Paulo e Júlio se aproximam do grupo e Carol oferece um "peixe" a eles, que fazem de conta que comem).

Turno 10 - Paulo: Eu quero mais.

Turno 11 - Júlio: Eu também.

Turno 12 - Mariana: Eu quero mais.

Turno 13 - Alice (Dirige-se à Carol): Dá só um pra cada. (Dirigindo-se a Paulo, exclama) Toma, vai-te embora. Não tem mais, menino.

Turno 14-Carol: Pode dar pra ele.

As crianças participantes deste episódio também tinham idade variando entre 3 anos e 11 meses a 5 anos, período denominado por Mukhina (1995) de pré-escolar mediano. Uma delas, Clara, também participou do episódio "Tomando banho na maré". Da mesma forma que na brincadeira anterior, elas também não chegaram a combinar sobre o que iam brincar. Não discutiram acerca dos papéis a serem representados e nem dos significados atribuídos aos objetos. $\mathrm{O}$ enredo da brincadeira foi iniciado por Carol, uma das meninas com mais idade da turma e mantido por ela durante todo o episódio. Carol "preparou o fogo" para "assar os peixes". Ao ver Clara se aproximar a convidou para brincar e a menina aceitou o convite. Mariana chegou depois e também entrou na brincadeira. Alice, Paulo e Júlio também se aproximaram do grupo e começaram a brincar.

Neste episódio temos quatro crianças desempenhando papéis. Carol que fez o papel de um adulto que assa e distribui peixe. Alice, que desempenhou o papel de ajudante de Carol. Clara que fez o papel da "vizinha" e Mariana, Paulo e Júlio representaram as pessoas (crianças, talvez) que eram alimentadas. Carol atribuiu significados aos objetos (cadeira da sala/fogão; um encosto de cadeira/grelha; pedras, pedaços de telha e folhas/carvão e raízes/peixes). Com exceção da cadeira, todos os demais objetos foram recolhidos por Clara no terreiro da escola.

Observa-se que o contexto histórico-cultural da Ilha do Combu está bem refletido nesse episódio. $\mathrm{O}$ argumento da brincadeira é assar peixes, uma atividade típica dos moradores da Ilha. Crianças bem pequenas já conhecem as regras dessa atividade (conteúdo). Sabem que para assar um peixe, é necessário, primeiramente, escamá-lo e preparar o fogo. Compreendem o que é escamar. Sabem também que após colocar no fogo é preciso dar um tempo para o peixe assar e só depois comer. Utilizam o significado de boia para comida, o que náo é comum a todos os lugares. Além disso, demonstram conhecer nomes de peixes típicos da Amazônia, como é o caso do mapará, largamente utilizado como alimento na Ilha. 
A análise do episódio indicou que significados importantes presentes no contexto histórico-cultural das crianças, tais como "escamar", "boia e "mapará", estão sendo internalizados por intermédio da brincadeira. Também coloca em evidência aspectos afetivos do processo de construção de significados. As falas de Alice e Carol são indicativas de que nessa comunidade, apesar das pessoas terem poucos recursos materiais, sabem compartilhar e esperar a vez. Por sua vez, a fala de Carol, no turno 9, "Vizinha, essa comida estava táo gostosa, depois eu volto pra comer a sobremesa" mostra que apesar das dificuldades geográficas reduzirem as possibilidades de relaçóes de vizinhança entre os moradores da Ilha, as crianças parecem apreciar e manter relaçôes amistosas com os vizinhos.

\section{Considerações Finais}

O processo de humanização de uma criança não é uma tarefa simples. Como mostrou Leontiev (1978), a cultura não é algo dado gratuitamente às crianças. Ela está apenas posta e sua internalização requer a atividade do sujeito. Não se trata também de uma operação de simples transferência de práticas e conteúdos culturais do plano social para o plano individual. Trata-se de um processo de reconstituição em e pela criança de algo já construído pelo gênero humano e que constitui sua história. Os estudos de Vigotski e outros autores da teoria histórico-cultural apontam que esse processo é de natureza semiótica. Nesse sentido, estudar o conteúdo semântico das brincadeiras de faz de conta podem fornecer indícios importantes do processo de humanização.

A breve descrição de aspectos do contexto histórico-cultural da Ilha do Combu e a análise das falas durante dois episódios de brincadeiras de faz de conta revelam indícios de como as crianças dessa comunidade estão se constituindo como sujeitos em interação com seus contextos específicos de vida. Os argumentos e os conteúdos das brincadeiras revelam a existência de uma complexa rede de significados compartilhados pelas crianças da turma de educação infantil da Unidade Pedagógica da Ilha do Combu, no qual podem ser reconstituídos aspectos importantes da realidade social da comunidade, como, por exemplo, as atividades econômicas, papéis sociais, relaçôes familiares e de vizinhança e práticas culturais da Ilha, mostrando que está em curso a constituição de uma subjetividade eminentemente ribeirinha.

Nesse sentido, o estudo confirma a proposição de Vigotski (2008), de que a brincadeira de faz de conta é uma atividade humana, mediada por instrumentos físicos e simbólicos, na qual a criança participa na condição de sujeito, por isso não apenas reproduz a sua realidade histórico-cultural, mas a recria pela possibilidade de lidar com significados culturais. 
Os resultados do estudo também trazem desdobramentos para se pensar a presença da brincadeira de faz de conta nos contextos de educação infantil. Sabendo da importância das interaçóes dialógicas para o processo de humanização, reforçam a ideia de que as propostas pedagógicas destinadas à educação da infância destinem tempo e espaço para essa atividade infantil. $\mathrm{O}$ fato das crianças da Ilha enfrentarem dificuldades para encontrar parceiros para brincar ressalta a importância da escola da comunidade e, especialmente, da turma de educaçáo infantil, como um lócus propulsor da interaçáo entre as crianças.

Finalmente, o estudo confirma a ideia de que a brincadeira de faz de conta é um campo fértil para observaçóes de indícios de como a criança internaliza as relaçóes sociais e constrói suas funçóes psicológicas superiores. No entanto, como assinala Prestes (2012), os adultos, especialmente os/as professores/as de Educaçâo Infantil, precisam ter muita cautela ao interpretar os conteúdos presentes nas brincadeiras, para não tirarem conclusôes precipitadas das observaçôes realizadas e nem fazerem intervençôes inadequadas. É importante que considerem as características da brincadeira de faz de conta apontadas por Vigotski (2008). Ao brincar, a criança se apoia nas regras da vida real, porém, a situação criada é imaginária, fruto de um processo de generalização de várias experiências. Dessa forma, a brincadeira não é uma reprodução literal da realidade vivida pela criança, mas um ato da "mais autêntica e verdadeira criação" (VYGOTSKY, 2008, p. 17). Isso ressalta a importância de estudos sobre as formas de mediação dos/as professores/as nas brincadeiras de faz de conta que se processam no contexto das turmas de Educação Infantil.

\section{Notas}

${ }^{1}$ Neste trabalho, entendo contexto histórico-cultural na perspectiva de Rossetti-Ferreira et al. (2004, p. 26), que afirma que os contextos "[...] são constituídos pelo ambiente físico e social, pela sua estrutura organizacional e econômica, sendo guiados por funçôes, regras, rotinas e horários específicos. Eles definem e são definidos pelo número e características das pessoas que os frequentam, sendo ainda marcados pela articulação da história geral e local, entrelaçadas com os objetivos atuais, com os sistemas de valores, as concepçóes e as crenças prevalentes. São, também, definidos por e definem os papéis sociais e as formas de coordenação de papéis/posicionamentos, contribuindo para a construção das relaçóes profissionais, pessoais, afetivas e de poder entre os seus participantes". 
${ }^{2}$ O termo pré-escolar é utilizado por Mukhina (1995) segundo a proposição de Vigotski (2006, 2008). O autor, ao falar sobre as diversas idades do ser humano, utiliza o termo criança pequena para se referir à criança na faixa etária de 0 a 3 anos e criança pré-escolar para a criança de 3 a 6 anos de idade.

\section{REFERÊNCIAS}

AMARAL, Edenia Maria Ribeiro do; MORTIMER, Eduardo Fleury. Uma metodologia para análise da dinâmica entre zonas de um perfil conceitual no discurso da sala de aula. In: SANTOS, Flávia Maria Teixeira, Santos; GRECA, Ileana Maria. A pesquisa em ensino de ciências no Brasil e suas metodologias. Ijuí, RS: Unijuí, 2006. p. 241-296.

DELARI JÚNIOR, Achilles. Vigotski: consciência, linguagem e subjetividade. Campinas, SP: Alínea, 2013.

DERGAN, João Marcelo Barbosa. História, memória e natureza: as comunidades da Ilha do Combu. 2006. Dissertação (Mestrado em História) - Universidade Federal do Pará, Belém, 2006.

ELKONIN, Daniil Borisovich. Psicologia do jogo. São Paulo: Martins Fontes, 1998.

FREIRE, Jacqueline Cunha da Serra. Juventude ribeirinha: identidade e cultura. Dissertação (Mestrado em Planejamento do Desenvolvimento) - Universidade Federal do Pará, Belém, 2002.

GÓES, Maria Cecília Rafael de. A natureza social do desenvolvimento psicológico. Cadernos CEDES, São Paulo, n. 24, 1991.

GÓES, Maria Cecília Rafael de. A abordagem microgenética na matriz históricocultural: uma perspectiva para o estudo da constituição da subjetividade. Cadernos CEDES, São Paulo, v. 20, n. 50, p. 9-25, 2000.

HARRIS, Mark. Life on the Amazon: the anthropology of a Brazilian peasant village. Oxford UK: University Press, 2000.

LEONTIEV. Alexis. Desenvolvimento do psiquismo. Lisboa: Livros Horizonte, 1978.

LEONTIEV, Alexis. Uma contribuição à teoria do desenvolvimento da psique infantil. In: VYGOTSKY, L. S. et al. Linguagem, desenvolvimento e aprendizagem. São Paulo: Ícone; Edusp, 1988. p. 59-84.

LOUREIRO, João de Jesus Paes. Cultura amazônica: uma poética do imaginário. São Paulo: Escrituras, 2000. 
MUKHINA, Valeria. Psicologia da idade pré-escolar. São Paulo: Martins Fontes, 1995.

PINO, Angel. O conceito de dimensão semiótica em Vygotsky e seu papel na explicação do psiquismo humano. Cadernos CEDES, São Paulo, n. 24, 1991.

PINO, Angel. As marcas do humano: as origens da constituição cultural da criança na perspectiva de Lev. S. Vigotski. São Paulo: Cortez, 2005.

BELÉM. Projeto Família Saudável. Belém, PA, 2001.

PRESTES, Zoia. L. S. Vigotski: algumas perguntas, possíveis respostas. In: VAZ, Alexandre Fernandes; MOMM, Caroline Machado (Org.). Educaçâo infantil e sociedade: questôes contemporâneas. Nova Petrópolis: Nova Harmonia, 2012. ROSSETI-FERREIRA, Maria Clotilde et al. (Org.). Rede de significaçôes e o estudo do desenvolvimento humano. Porto Alegre: Artmed, 2004.

VIGOTSKI, Lev Semionovitch A brincadeira e o seu papel no desenvolvimento psíquico da criança. Tradução de Zoia Prestes. Revista Virtual de Gestão de Iniciativas Sociais, n. 11, jun.2008. Disponível em: <http://www.ltds.ufrj.br/gis/anteriores/rvgis11.pdf>.

VIGOTSKI, Lev Semionovitch. O manuscrito de 1929: temas sobre a constituição cultural do homem. Educação \& Sociedade, Campinas, n. 71, p. 21-44, 2000a.

VIGOTSKI, Lev Semionovitch. Historia del desarrollo de las funciones psíquicas superiores. Obras escogidas. 2. ed. Madrid: Visor, 2000b. v. 3. p. 11- 340.

VIGOTSKI, Lev Semionovitch. Psicologia pedagógica. Porto Alegre: Artmed, 2003.

VIGOTSKI, Lev Semionovitch. Obras escogidas. Madrid: Visor; A. Machado Libros, 2006. v. 4.

VIGOTSKY, Lev Semionovitch. The problem of the cultural development of the child. In: VIGOTSKY, Lev Semionovitch. The Vygotsky reader. Oxford; Cambridge: Blackwell, 1994. p. 57-72.

WERTSCH, James; TULVISTE, Peteer. L. S. Vygotsky and contemporary developmental psychology. Developmental psychology, Michigan, v. 28, n. 4, p. 548$557,1992$. 


\section{The role of make-believe play in the humanization process of the riverine children in the Amazon}

\begin{abstract}
According to the cultural-historical theory, the human being humanizes himself by reconstituting on and for himself the historical features of humanity. This process occurs in social relations, through human activity mediated by physical and symbolic tools. In preschool, the make-believe play is the activity that guides development. When playing, the child discovers and appropriates the contents of its cultural surrounding, forming his/her human qualities. In this sense, the objective of this study is to analyze and discuss the role of make-believe play in the humanization process of children, studying children in a preschool class in a riverside school in the Amazon. The plays were transcribed, analyzed and organized into episodes according to the methodological principles of microgenetic analysis of culturalhistorical approach. The results demonstrate that children from Combu Island internalize their social relationships through shared meanings with partners at the play, becoming, in this way, Amazonian riverside children.
\end{abstract}

Keywords: Childhood. Preschool. Amazon.

\section{El rol del juego en el proceso de humanización de niños ribereños en un rio de Amazonía}

\section{Resumen}

De acuerdo con la teoría histórico-cultural el ser humano se humaniza reconstituyendo en si y para si las características históricas de la humanidad. Este proceso se produce en las relaciones sociales, a través de la actividad humana mediada por las herramientas físicas y simbólicas. En el preescolar, el juego de roles es la actividad que guía este proceso. En el juego, el niño descubre y se apropia de los contenidos de su universo cultural, formando sus cualidades humanas. En este sentido, el objetivo de este artículo es analizar y debatir el rol del juego en el proceso de humanización de los niños, a partir de un estudio de los niños de un grupo de educación infantil (preescolar) de una escuela a orillas de un río en la Amazonía. Los juegos fueron transcritos, analizados y organizados en episodios de acuerdo a los principios metodológicos de análisis microgenético de la matriz histórico-cultural. Los resultados demuestran que los nińos de la localidad Isla de Combu, por intermedio de significados compartidos en los juegos de roles, interiorizan sus relaciones sociales, constituyéndose, de esta manera, como niños de la orilla de los ríos Amazónicos.

Palabras claves: Infancia. Educación infantil. Amazónia. 
Sônia Regina dos Santos Teixeira

E-mail: soniaregina.st@uol.com.br

Recebido em: 23/4/2014

Aprovado em: 26/8/2014 